\title{
Yttrium-90 radiosynoviorthesis hosszú távú (10 éves) eredményei inflammált térdarthrosisban
}

\author{
Prospektiv obszervációs vizsgálat \\ Szentesi Margit dr. ${ }^{1}$ - Nagy Zoltán dr. ${ }^{2}$ - Géher Pál dr. ${ }^{1}$ \\ Papp István dr. ${ }^{3}$ - Kampen W. Uwe dr. ${ }^{4}$ \\ ${ }^{1}$ Budai Irgalmasrendi Kórház, Reumatológiai Centrum, Semmelweis Egyetem, \\ III. Belgyógyászati Klinika, Reumatológiai Tanszéki Csoport, Budapest \\ ${ }^{2}$ Budai Irgalmasrendi Kórház, Nukleáris Medicina Osztály, Budapest \\ ${ }^{3}$ Pécsi Tudományegyetem, Egészségtudományi Kar, Doktori Iskola, XV. ker. Háziorvosi Rendelő, Pécs \\ ${ }^{4}$ Nuclear Medicine Spitalerhof, Hamburg, Germany
}

Bevezetés: A radiosynoviorthesist (RSO) fájdalmas, terápiarezisztens, krónikus synovitis kezelésére alkalmazzuk az 1950-es évek óta, de a hosszú távú hatások felmérésére eddig nem készültek prospektív ellenőrzött vizsgálatok. Célkitüzés: Ennek a prospektív, obszervációs vizsgálatnak az volt a célkitűzése, hogy felmérje az izotópos synovectomia hatékonyságát inflammált térdosteoarthritisben (OA) 10 éves nyomon követésben.

Módszer: Alapos elókészítés után a radionuklid-kezelést 90-Yttrium-citráttal végeztük Kellgren-Lawrence I-II. $(\mathrm{n}=69)$ és III. stádiumú ( $\mathrm{n}=72)$ osteoarthritises betegekben, intraarticularis injekció formájában.

Eredmények: A korai radiológiai stádiumban levő osteoarthritises betegekben „kiváló/jó” eredményeket értünk el már 1 év után az esetek 82,5\%-ában, és 73,7\%-ot a 8 éves kontrollvizsgálatokon. A felmérés az ízületi fájdalomra, a mobilitásra és a mozgásfunkciók megtartására vonatkozott. 10 évvel a beadás után az eredményesség 50\%-ra csökkent, feltehetôen a korral járó degeneratív folyamatok progressziója miatt. A III. stádiumú betegekben (akiknél az osteoarthritis előrehaladottabb volt) kezdetben 45,9\%-os eredményt értünk el, és ez 41,2\%-ra esett vissza a 8 éves utánkövetés során. Ebben a csoportban a betegek száma csökkent a 8-10. évre, azaz a 8. évben 51 beteg maradt, majd a 9. évben 30 beteg, a 10. évben pedig 9 beteg. Az utolsó évben az alacsony betegszám miatt a klinikai válaszok nem voltak biztonságosan megítélhetôk.

Következtetés: Az osteoarthritises ízületekben alkalmazott RSO hosszú távú eredménye a legtöbb betegben „kiváló” vagy ,jó” volt. A radiokolloid hatása hosszú távon fennmarad, a 8-10. éves gyengébb eredmények az életkor előrehaladásával jelentkező degeneratív folyamatoknak és az alacsony betegszámnak tudható be. Ismert, hogy a hatékonyság függ a kezdeti diagnózistól (OA, RA, SpA, PsA, AHA, ReA stb.), a radiológiai stádiumtól (Kellgren-Lawrence I-IV.), illetve a synovitis score-tól. Eredményeink a nemzetközi tapasztalatokhoz hasonlóan arra utaltak, hogy a radiációs synovectomia alkalmazása elsősorban az alacsonyabb radiológiai stádiumban levő betegeknek javallott. Orv Hetil. 2020; 161(43): 1831-1839.

Kulcsszavak: osteoarthritis, radiosynoviorthesis, radiációs synovectomia, 90-Yttrium, Kellgren-Lawrence

\section{Long-term (10 year) results of Yttrium-90 radiosynoviorthesis in inflammed knee osteoarthritis}

\section{A prospective observational study}

Introduction: Since the 1950s, radiosynoviorthesis (RSO) has been used for the treatment of inflammatory synovitis in joint diseases, however, on controlled studies no long-term results have been published.

Objective: The aim of this prospective observational study was to evaluate response rates after radionuclide therapy in patients suffering from painful knee osteoarthritis $(\mathrm{OA})$ over a period of 10 years.

Method: After careful selection and preparation of the patients, the radionuclide therapy with colloidal 90-yttrium was administered in osteoarthritis patients of Kellgren-Lawrence grade I-II $(n=69)$ and grade III $(n=72)$ in the form of intra-articular injection. 
Results: In patients with early-stage disease, “excellent/good" responses with respect to pain, joint mobility, and function were observed in $82.5 \%$ for 1 year and $73.7 \%$ for 8 years after therapy. Responses declined to $50 \%$ at 10 years post-treatment. In grade III patients, an "excellent/good" response was observed in $45.9 \%$; a decline to $41.2 \%$ after 8 years. In this group, the number of patients available for follow-up after 9 and 10 years dropped significantly from 50 patients after 8 years, to only 30 patients after 9 years, and to 9 patients after 10 years. Due to this low number of patients in the last year the response rates were not considered significant.

Conclusion: The RSO administered to osteoarthritic joints provided „excellent/good” results on long term for the majority of the patients. The effect of the radiocolloid was sustainable, the weaker results in the 8-10 years were due to the degenerative progression of this disease with age. The effectiveness was dependent on the initial diagnosis (i.e., RA, OA, SpA, PsA, AHA, ReA, etc.), and the radiological stage (i.e., Kellgren-Lawrence stages I-IV) and synovitis score. Similar to the international experience, the RSO is advised to be administered in early radiological stages of the disease.

Keywords: osteoarthritis, radiosynoviorthesis, radiation synovectomy, 90-yttrium

Szentesi M, Nagy Z, Géher P, Papp I, Kampen WU. [Long-term (10 year) results of Yttrium-90 radiosynoviorthesis in inflammed knee osteoarthritis. A prospective observational study]. Orv Hetil. 2020; 161(43): 1831-1839.

(Beérkezett: 2020. január 13.; elfogadva: 2020. május 19.)

\begin{abstract}
Rövidítések
99m-Tc = 99m-technéciumizotóp; 131-J = 131-es jódizotóp; $198-\mathrm{Au}=198$-as aranyizotóp $; \mathrm{ACPA}=($ anti-citrullinated protein antibody) citrullinált fehérje elleni antitest; AHA = akut haemophiliás arthritis; $\mathrm{AP}=$ anteroposterior; ARA/EULAR = (American College of Rheumatology/European League Against Rheumatism) Amerikai Reumatológiai Társaság/Európai Reumaellenes Liga; $\mathrm{Co}=$ (comparative group) kontrollcsoport; CT = (computed tomography) számítógépes tomográfia; $\mathrm{EANM}=$ (European Association of Nuclear Medicine) Európai Nukleáris Medicina Szövetség; GDP = (gross domestic product) bruttó hazai termék; IgG2 = G2-típusú immunglobulin; $\mathrm{IgM}=\mathrm{M}$-típusú immunglobulin; ILl = interleukin- $\mathrm{I} ; \mathrm{K}-\mathrm{L}=$ (Kellgren-Lawrence radiological stage) Kellgren-Lawrenceféle radiológiai beosztás; $\mathrm{MBq}=$ megabecquerel; $\mathrm{MRI}=($ magnetic resonance imaging) mágnesesrezonancia-képalkotás; $\mathrm{NGF}=$ (nerve growth factor) idegi növekedési faktor; OA = osteoarthritis; PET $=$ (positron-emission tomography) pozitronemissziós tomográfia; PsA $=$ (psoriatic arthritis) arthritis psoriatica; PtA = posttraumás arthritis; PVNS = pigmentált villonodularis synovitis; RA = rheumatoid arthritis; ReA $=($ arthritis reactive) reaktív arthritis $(\mathrm{M}$. Reiter $)$; ROI $=$ (region of interest) célzóna; $\mathrm{RSO}=$ radiosynoviorthesis; $\mathrm{SpA}=$ spondylitis ankylopoetica; $\mathrm{VAS}=($ visual analogue scale $)$ vizuális analóg skála
\end{abstract}

Idős betegekben az osteoarthritis (OA) az egyik leggyakoribb degeneratív ízületi betegség, amely 65 év fölött a lakosság 34\%-ában fájdalmat és mozgáskorlátozottságot okoz [1]. Európában legalább 40 millió ember lehet érintett [2]. Hasonló adatokat publikáltak Ázsiában, és ezek a populáció fokozatosan magasabb átlagéletkorára és elöregedésére utalnak az egész világon [3]. Ez egyben gazdasági és szociológiai nehézségeket jelent: az OA a musculoskeletalis betegségek közt a leggyakrabban felállított diagnózis [4], és olyan országoknak, mint az Egye- sült Államok, Kanada, Nagy-Britannia vagy Franciaország, a GDP 1-2,5\%-át viszi el [5]. Sok éven keresztül úgy tekintettek az OA-ra, mint az ízületek mechanikai terhelése és a teljesítőképesség közti különbségből eredő betegségre, és magát az ízületben lezajló gyulladásos folyamatot másodlagos jelenségnek tekintették [6]. Elsősorban a nagy teherviselö csontokat érinti, mint a térd és a csípő. Jellegzetessége az ízületi porcszövetek degenerációja (arthrosis), mérsékelt intraarticularis gyulladással (arthritis), enyhe vagy közepes synovitisszel és a subchondralis csontot érintő elváltozásokkal. Annak ellenére, hogy sokáig noninflammatorikus folyamatnak tekintették, manapság mind több evidencia jelenik meg a gyulladásos citokinek és metalloproteinek szerepére [7, 8]. A primer OA elsősorban az időskor betegsége; kezdetben a betegek tünetmentesek, de 75 év fölött már több mint $80 \%$-ban vannak radiológiailag kimutatható eltérések. A prevalencia 50 éves kortól emelkedik, elsősorban nőkben, és 55 éves kor körül a betegek 10\%-ának már vannak tünetei [9-11].

Lequesne javasolta, hogy azokat a betegeket, akik évente több mint $2 \mathrm{~mm}$ ízületi szúkületet mutatnak, vagy több mint 50\%-át elveszítik az ízületi résnek egy év alatt, tekintsék 'gyors-progresszív' OA-betegeknek [12]. Az állatkísérletek arra utalnak, hogy gyulladás esetén az érrendszer penetrál az osteochondralis junctióba, illetve a porcos állományba [13]. Az ereket kísérő nociceptiv idegvégződések hozzájárulnak az ízületi fájdalmakhoz. Ezt a hipotézist erősítik azok a klinikai vizsgálatok, amelyek arra utalnak, hogy a fájdalom csökkenthető az idegi növekedési faktor (NGF, nerve growth factor) gyógyszeres blokkolásával [14].

A humanizált monoklonális, G2-típusú immunglobulinok (IgG2) kötődnek az NGF-hez, és ezáltal meggá- 
tolják a trkA- vagy p75-receptorokkal való interakciót, jelentôs fájdalomcsillapító hatást érve el [15].

Az ízületből kifutó nociceptiv jelek 'centrális szenzitizációt' eredményeznek, tehát a synovitis meghatározó oka ennek a kialakuló érzetnek [16]. Az új képalkotó eljárásokkal (ultrahang, MRI, CT, PET) a synovitis már korai fázisban felismerhető; az esetek 33-52\%-ában az ultrahang jelzi a korai gyulladásos jeleket. Az MRI alkalmazásával ezek az elváltozások még korábban kimutathatók [17].

Rheumatoid arthritises (RA) betegekben a makrofágspecifikus radioaktív tracer (kontrasztanyag) már szubklinikai állapotban jelzi a synovitist [18]. A synovialis gyulladás, a tünetek súlyossága és a centrális szenzitizáció összefüggése miatt a synovialis membrán lett a kezelések célpontja, beleértve a radiokolloidos (radiosynoviorthesis [RSO]-) térdkezeléseket is [19].

Első alkalommal 1952-ben Fellinger és Schmid publikálta eredményeit az intraarticularisan adott radionuklidokkal (3,7-7,4 MBq 131-J és $37 \mathrm{MBq}$ 198-Au) [20]. RA-betegekben a fájdalom jelentős csökkenését észlelték. Ma már több mint 60 éve alkalmazzuk a radiációs synovectomiát terápiarezisztens krónikus ízületi gyulladások kezelésére. Ugyanakkor a legtöbb publikáció rövid, néhány hónapos vagy pár éves eredményekról számol be. Jelenlegi prospektív obszervációs vizsgálatunknak az volt a célja, hogy felmérje az RSO hosszú távú hatékonyságát a térd-OA-ban szenvedő betegekben. A kezelés előtti, illetve az egy évvel a beadás utáni klinikai adatokat értékeltük és hasonlítottuk össze a későbbi eredményekkel.

\section{Betegek és módszerek}

A szimptomatikus OA-ban szenvedő betegeknek felajánlottuk a hosszú távú utánkövetés lehetőségét. Először 1 éves, majd 5 éves, illetve utána minden évben, illetve a 10. évben is felméréseket végeztünk. Összesen 141 beteg egyezett bele, hogy részt vegyen ebben a hosszú távú utánkövetésben.

Az RSO-kezelés beválasztási kritériumai: 4-6 hónapja fennálló, krónikus, perzisztáló synovitis, amely nem reagál a konvencionális kezelésekre, beleértve az ízületbe adott 3-6, tartós hatású kortikoszteroidinjekciót. A térdek Kellgren-Lawrence (K-L) radiológiai stádiuma IIII. Kizárási kritériumok voltak: terhesség, laktáció, bakteriális infekció, rupturált poplitealis cysta, bőrelváltozás a térd fölött, illetve K-L IV. stádiumú térdízület.

A betegek (45 férfi, 96 nő) átlagos életkora 61,5 év volt (40-86 között). A kezelt ízületek közül 71 jobb és 70 bal térdízület volt. Az RSO előtt az OA fennállási ideje átlagosan 12,3 év volt (azaz 5-20 év között). Figyelembe vettük az RSO előtti intraarticularis szteroid ízületi injekciók számát, amely átlagosan 8,7 volt ( $1-15$ között). Jelen munkánkban RA-betegek adatai nem szerepelnek. A RA kizárása az ARA/EULAR kritériumoknak megfelelően történt (ACPA-pozitivitás) [21]. Az
RSO alkalmazása előtt minden beteg mindkét térde 99m-Tc (technécium-pertechnát)-lágyrészszcintigráfián esett át, az aktív synovitis fennállásának igazolására és a Baker-cysta kizárására.

A térdek AP irányú, illetve az érintett térdnek az oldalnézetét elemezzük két célzónában (region of interest ROI), a proximalis sípcsontrégiót használva a háttérkorrekcióhoz. Összehasonlítjuk a radioizotóp akkumulációját a kezelt térdben, és egy távoli lágy szövetben ugyanazon az oldalon. Mindegyik térdről numerikus értéket kapunk, melyet synovitisindexnek nevezünk.

Tc-index $=\frac{\text { Aktivitás }(\text { maximum }) \text { a térd felett }(\mathrm{mm})-\text { háttér aktivitás }}{\text { Aktivitás a standard felett }(\mathrm{mm})-\text { háttér aktivitás }}$

$\mathrm{Az}$ RSO előtt minden beteg ultrahangvizsgálaton esett át; meghatározásra került a synovialis folyadék mennyisége, illetve a synovialis membrán vastagsága a középvonalban, a femurcondylusok mellett lateralisan és

1. táblázat | Orvosi pontozási rendszer (objektív pontrendszer) a funkcionális paraméterek objektív megítélésére

\begin{tabular}{|c|c|c|}
\hline Paraméter & Objektív mérési értékek & Pontszám \\
\hline $\begin{array}{l}\text { Az ízületi duzzanat- } \\
\text { körfogat csökkenése } \\
\text { (cm-ben) }\end{array}$ & $\begin{array}{l}>7,1 \mathrm{~cm}, \text { nincs duzzanat } \\
5,1-7,0 \mathrm{~cm} \\
3,1-5,0 \mathrm{~cm} \\
0,1-3,0 \mathrm{~cm}\end{array}$ & $\begin{array}{l}4 \\
3 \\
2 \\
1\end{array}$ \\
\hline $\begin{array}{l}\text { Az ízületi funkció } \\
\text { (flexió) } \\
\text { javulása }\end{array}$ & $\begin{array}{l}20^{\circ} \text { és felette, illetve teljes } \\
\text { funkció } \\
15^{\circ} \\
10^{\circ} \\
5^{\circ} \\
0^{\circ} \text { vagy romlott }\end{array}$ & $\begin{array}{l}4 \\
3 \\
2 \\
1 \\
0\end{array}$ \\
\hline $\begin{array}{l}\text { A flexiós kontraktú- } \\
\text { ra mértéke a kezelés } \\
\text { után }\end{array}$ & $\begin{array}{l}0^{\circ}(\text { teljes extenzió }) \\
1-5^{\circ} \\
6-10^{\circ} \\
11-15^{\circ} \\
16-20^{\circ} \text { és felette }\end{array}$ & $\begin{array}{l}4 \\
3 \\
2 \\
1 \\
0\end{array}$ \\
\hline $\begin{array}{l}\text { A fájdalomskála } \\
\text { pontértékének } \\
\text { javulása } \\
(\text { VAS } 1-10 \mathrm{~cm} \text { ) }\end{array}$ & $\begin{array}{l}8-10 \text { vagy nincs fájdalom } \\
5-7 \\
3-4 \\
1-2 \\
0 \text { vagy romlott }\end{array}$ & $\begin{array}{l}4 \\
3 \\
2 \\
1 \\
0\end{array}$ \\
\hline Ízületi melegség & $\begin{array}{l}\text { Nincs } \\
\text { Van }\end{array}$ & $\begin{array}{l}1 \\
0\end{array}$ \\
\hline $\begin{array}{l}\text { Járóképes } \\
\text { Járóképtelen }\end{array}$ & $\begin{array}{l}+ \\
-\end{array}$ & $\begin{array}{l}1 \\
0\end{array}$ \\
\hline $\begin{array}{l}\text { A járásteljesítmény } \\
\text { javulása időben }\end{array}$ & $\begin{array}{l}\text { Korlátlan } \\
5-10 \text { óra } \\
2-5 \text { óra } \\
1-2 \text { óra } \\
0,5-1 \text { óra } \\
0,5 \text { óra vagy romlott }\end{array}$ & $\begin{array}{l}5 \\
4 \\
3 \\
2 \\
1 \\
0\end{array}$ \\
\hline $\begin{array}{l}\text { A beavatkozás utáni } \\
\text { ízületi punkciók } \\
\text { száma }\end{array}$ & $\begin{array}{l}0 \\
\text { 1-2 punkció } \\
\text { 2-nél több punkció }\end{array}$ & $\begin{array}{l}2 \\
1 \\
0\end{array}$ \\
\hline $\begin{array}{l}\text { A beavatkozás után } \\
\text { történt-e mútét? }\end{array}$ & $\begin{array}{l}\text { Nem } \\
\text { Igen }\end{array}$ & $\begin{array}{l}2 \\
0\end{array}$ \\
\hline
\end{tabular}

Miután a nyugalmi és a terhelési fájdalom értékelését külön pontoztuk, az objektív értékelés maximális pontszáma: 31 . 
2. táblázat A radiosynoviorthesis szubjektív pontrendszere és összértékelé se. A beteg által kitöltött szubjektív pontrendszer (VAS)

\begin{tabular}{llc}
\hline Célkitűzés & Értékelés & Pontszám \\
\hline Javulás a fájdalom- & $8-10$ pont vagy nincs fájdalom & 4 \\
érzetben & $5-7$ pont, jelentős javulás & 3 \\
VAS: $1-10 \mathrm{~cm}$ & $3-4$ pont, közepes javulás & 2 \\
& $1-2$ pont, enyhe javulás & 1 \\
& 0 pont, stagnálás vagy & 0 \\
& rosszabbodás & \\
&
\end{tabular}

A radiosynoviorthesis összértékelése

Maximális pontszám: $31+4=35$

\begin{tabular}{lc}
\hline - Kiváló & $29-35$ \\
\hline - Jó & $22-28$ \\
\hline - Közepes & $15-21$ \\
\hline - Gyenge & $8-14$ \\
\hline - Rossz & $0-7$ \\
\hline
\end{tabular}

VAS = vizuális analóg skála

medialisan. Felmérésre kerültek a condylusok, a meniscusok, a ligamentumok és a porcfelszínek. Ultrahangvizsgálat segítségével vizsgáltuk a Baker-cysta jelenlétét, falvastagságát és esetleges rupturáját. 25 betegnél az RSO után is végeztünk ultrahangvizsgálatot.

Az RSO előtt az ízületekről 2 irányú terheléses, összehasonlító térd- és a patella axiális röntgenfelvétele készült. A radiológiai beosztás az ismert $\mathrm{K}-\mathrm{L}$-kritériumok alapján történt [22]. K-L IV. stádiumú betegeket nem vontunk be a vizsgálatba, hiszen ebben a stádiumban protézismútétet kell végezni. Előrehaladott térdízületi destrukció esetében az európai irányelvek (EANM) sem javasolják az RSO alkalmazását, sőt a „relatív kontraindikációk" közé sorolják [23]. A radiológiai beosztás alapján 9 betegnek volt K-L I., 60 betegnek K-L II., és 72 betegnek K-L III. fokú OA a térdében. A betegek átlagosan 9,3 intraarticularis kortikoszteroidinjekciót kaptak az RSO előtt. 86 beteg kapott röntgenbesugárzást az RSO előtt, 4 betegnél kémiai synovectomia történt, illet- ve 21 betegnek volt sebészeti synovectomiája. Az RSO alkalmazása a módszertani levélnek megfelelően történt [23].

Az RSO hatékonyságának felmérése a mellékelt pontrendszerben meghatározott kritériumoknak megfelelően történt (1. táblázat). A kezelőorvos felmérte az ízületek mozgathatóságát, a flexiót, a flexiós kontraktúra mértékét, megmérte a térd körfogatát, a járási kapacitást, a nyugalmi és a terhelési fájdalmat, illetve az ízületi melegséget és az RSO után kapott injekciók számát. Az orvos által adható maximális objektív pontszám: 31. A betegeknek fájdalomskálát (VAS) kellett kitölteniük (1-4 pont) (2. táblázat).

Az objektív és a szubjektív pontok összege 35. A 2935 pontot „kiválónak” („excellent”, jelentős javulás), a 22-28 pontot „jónak” ( good”), a 15-21 pontot „közepesnek” („medium”), a 8-14 pontot „gyengének” ( „weak”) és a 0-7 pontot „elégtelennek” („bad”) értékeltük.

\section{Eredmények}

Egészséges térdízületben a szcintigráfiával mért synovitisindex normálesetben $0,8 \pm 0,2$; az RSO előtt a kezelésekre kiválasztott betegek térdében átlagosan $1,79 \pm 0,5$ értékeket találtunk. A radiokolloid-kezelésen átesett betegek térdében 10 év távlatában átlagosan 1,18 \pm 0,3 volt az érték, tehát a gyulladás lényegesen csökkent. Ebben a hosszú távú, prospektív, obszervációs vizsgálatban alapadatnak vettük az RSO után mért egyéves klinikai értékeket, és ezeket hasonlítottuk össze az 5, illetve 10 éves adatokkal (3., 4. és 5. táblázat).

Mivel alacsony volt a K-L I. stádiumban levő betegek száma $(n=9)$, ezeket kombináltuk a K-L II. stádiumban levő betegekkel. A 3. táblázatban az OA-betegek ( $\mathrm{n}=$ 141) válaszadása látható. Ha a 141 OA-beteg 1 éves eredményeit hasonlítjuk össze az 5 éves eredményekkel, nem találunk szignifikáns különbséget. Ha a 6, 7, 8, 9 és 10 éves eredményeket hasonlítjuk össze az 1 éves eredményekkel, itt sem találunk szignifikáns eltérést. Ha a K-L I-II. alcsoportba tartozó 69 beteg eredményeit ele-

3. táblázat | Osteoarthritises betegek válaszadása a pontrendszer alapján $(\mathrm{n}=141)$ radiosynoviorthesis $(\mathrm{RSO})$ után

\begin{tabular}{|c|c|c|c|c|c|c|c|c|}
\hline $\begin{array}{l}\text { RSO utáni } \\
\text { évek }\end{array}$ & $\begin{array}{c}\text { A betegek száma } \\
\mathrm{n}\end{array}$ & $\begin{array}{l}\text { Kiváló } \\
\text { n (\%) }\end{array}$ & $\begin{array}{c}\text { Jó } \\
\text { n (\%) }\end{array}$ & $\begin{array}{c}\text { Közepes } \\
\text { n }(\%)\end{array}$ & $\begin{array}{l}\text { Gyenge } \\
\mathrm{n}(\%)\end{array}$ & $\begin{array}{l}\text { Rossz } \\
\mathrm{n}(\%)\end{array}$ & $\begin{array}{c}\text { Kiváló + Jó } \\
\text { n (\%) }\end{array}$ & Szignifikancia \\
\hline 1 & 141 & $45(31,9)$ & $45(31,9)$ & $36(25,5)$ & $15(10,6)$ & 0 & $90(63,8)$ & \\
\hline 5 & 141 & $42(29,8)$ & $45(31,9)$ & $33(23,4)$ & $18(12,7)$ & $3(2,1)$ & $87(61,7)$ & ns \\
\hline 6 & 138 & $54(39,1)$ & $27(19,5)$ & $30(21,7)$ & $24(17,4)$ & $3(2,2)$ & $81(58,6)$ & ns \\
\hline 7 & 132 & $60(45,5)$ & $15(11,4)$ & $33(25)$ & $21(15, .9)$ & $3(2,3)$ & $75(56,9)$ & ns \\
\hline 8 & 108 & $45(41,7)$ & $18(16,7)$ & $24(22,2)$ & $18(16,7)$ & $3(2,8)$ & $63(58,4)$ & ns \\
\hline 9 & 66 & $24(36,4)$ & $15(22,7)$ & $12(18,2)$ & $15(22,7)$ & 0 & $39(58,3)$ & ns \\
\hline 10 & 33 & $9(27,27)$ & $9(27,27)$ & $6(18,2)$ & $9(27,27)$ & 0 & $18(54,54)$ & ns \\
\hline
\end{tabular}

ns = nem szignifikáns 
4. táblázat | A Kellgren-Lawrence I-II. stádiumban levő osteoarthritises betegek válaszadása $(\mathrm{n}=69)$. Radiosynoviorthesis $($ RSO) után

\begin{tabular}{|c|c|c|c|c|c|c|c|c|}
\hline $\begin{array}{l}\text { RSO utáni } \\
\text { évek }\end{array}$ & A betegek száma & $\begin{array}{c}\text { Kiváló } \\
\text { n (\%) }\end{array}$ & $\begin{array}{c}\text { Jó } \\
\text { n (\%) }\end{array}$ & $\begin{array}{c}\text { Közepes } \\
\text { n (\%) }\end{array}$ & $\begin{array}{c}\text { Gyenge } \\
\mathrm{n}(\%)\end{array}$ & $\begin{array}{l}\text { Rossz } \\
\mathrm{n}(\%)\end{array}$ & $\begin{array}{c}\text { Kiváló + Jó } \\
\text { n }(\%)\end{array}$ & Szignifikancia \\
\hline 1 & 69 & $33(47,8)$ & $45(31,9)$ & $24(34,7)$ & 0 & - & $57(82,5)$ & \\
\hline 5 & 69 & $30(43,5)$ & $45(31,9)$ & $24(34,8)$ & $3(4,3)$ & - & $54(78,3)$ & ns \\
\hline 6 & 66 & $42(63,6)$ & $27(19,5)$ & $9(13,6)$ & $6(8,7)$ & - & $51(51)$ & ns \\
\hline 7 & 66 & $42(63,63)$ & $6(9,1)$ & $15(22,7)$ & $3(4,5)$ & - & $48(72,7)$ & ns \\
\hline 8 & 57 & $36(63,2)$ & $18(16,7)$ & $6(10,5)$ & $3(5,2)$ & - & $42(73,7)$ & ns \\
\hline 9 & 36 & $18(50)$ & $15(22,7)$ & $3(8,3)$ & $6(6,7)$ & - & $21(58,3)$ & $\mathrm{p}=0,0063$ \\
\hline 10 & 24 & $9(37)$ & $9(27,27)$ & $3(12,5)$ & $6(25)$ & - & $12(50)$ & $\mathrm{p}=0,0019$ \\
\hline
\end{tabular}

ns = nem szignifikáns

5. táblázat | A Kellgren-Lawrence III. stádiumban levő osteoarthritises betegek válaszadása $(\mathrm{n}=72)$.

\begin{tabular}{|c|c|c|c|c|c|c|c|c|}
\hline $\begin{array}{l}\text { RSO utáni } \\
\text { évek }\end{array}$ & $\begin{array}{c}\text { A betegek száma } \\
\mathrm{n}\end{array}$ & $\begin{array}{l}\text { Kiváló } \\
\mathrm{n}(\%)\end{array}$ & $\begin{array}{c}\text { Jó } \\
\text { n (\%) }\end{array}$ & $\begin{array}{l}\text { Közepes } \\
\text { n (\%) }\end{array}$ & $\begin{array}{c}\text { Gyenge } \\
\mathrm{n}(\%)\end{array}$ & $\begin{array}{l}\text { Rossz } \\
\mathrm{n}(\%)\end{array}$ & $\begin{array}{c}\text { Kiváló + Jó } \\
\text { n (\%) }\end{array}$ & Szignifikancia \\
\hline 1 & 72 & $12(16,7)$ & $21(29,2)$ & $24(33,3)$ & $15(20,8)$ & 0 & $33(45,9)$ & \\
\hline 5 & 72 & $12(16,7)$ & $21(29,2)$ & $21(29,2)$ & $15(20,8)$ & $3(4,2)$ & $33(45,9)$ & ns \\
\hline 6 & 72 & $12(16,7)$ & $18(25)$ & $21(29,2)$ & $18(25)$ & $3(4,2)$ & $30(41,7)$ & ns \\
\hline 7 & 69 & $15(26,1)$ & $9(13)$ & $21(30,4)$ & $18(26,1)$ & $3(4,4)$ & $24(39,1)$ & ns \\
\hline 8 & 51 & $9(17,7)$ & $12(23,5)$ & $12(23,5)$ & $15(29,4)$ & $3(5,88)$ & $21(41,2)$ & ns \\
\hline 9 & 30 & $6(20)$ & $12(40)$ & $3(10)$ & $9(30)$ & 0 & $18(60,0)$ & \\
\hline 10 & 9 & 0 & $6(66,7)$ & 0 & $3(33,3)$ & 0 & $6(66,7)$ & \\
\hline
\end{tabular}

ns = nem szignifikáns

mezzük (4. táblázat), a statisztikai elemzés nem mutat szignifikáns különbséget az 1 és 5 éves, az 1 és 6 éves, az 1 és 7 éves és 1 és 8 éves eredmények között. Ha az 1 éves adatokat a 9 éves adatokkal hasonlítjuk össze, a különbség szignifikáns $(\mathrm{p}=0,0063)$. Ha az 1 éves és a 10 éves adatokat hasonlítjuk össze, a különbség szignifikáns $(\mathrm{p}=0,0019)$. A K-L III. csoportban (5. táblázat, $\mathrm{n}=$ $72)$ az 1 éves eredményeket az 5, 6, 7 és 8 éves eredményekkel összehasonlítva nincs szignifikáns különbség. A 9 és a 10 éves adatok nem voltak értékelhetók a betegek alacsony száma miatt.

Az RSO előtt adott ízületi injekciók száma átlagosan 8,7 volt. Az RSO után a 141 betegnek a 71 kezelt térde $(55,3 \%)$ nem kapott további ízületi injekciót, tehát a krónikus synovitis megszúnt, a kezelés hatásos volt. A synovitis 63 betegben nem szűnt meg, és a betegek újabb punkcióra szorultak.

Korábbi munkánkban [24] a szövettani változások felmérésére a RA-betegekben artroszkópos vizsgálatokat és szövettani mintavételt végeztünk az RSO előtt 6 héttel és eredményes RSO után fél, l vagy 2 évvel. Jelen munkánkban 20 inflammált arthrosisos (OA-) betegnél (14 nő, 6 férfi) végeztünk artroszkópos és szövettani vizsgálatot az RSO elótt és után. 2 beteg a K-L I. stádiumba, 16 beteg a II. stádiumba, 2 beteg a K-L III. stádiumba tartozott.
Az RSO előtti artroszkópos vizsgálatoknál proliferáló, hyperaemiás, oedemás synovium látható, gyulladásos „szőlőfürtszerü” képződményekkel (1. ábra). Eredményes radionuklid-kezelés után a synovium hyperaemiája

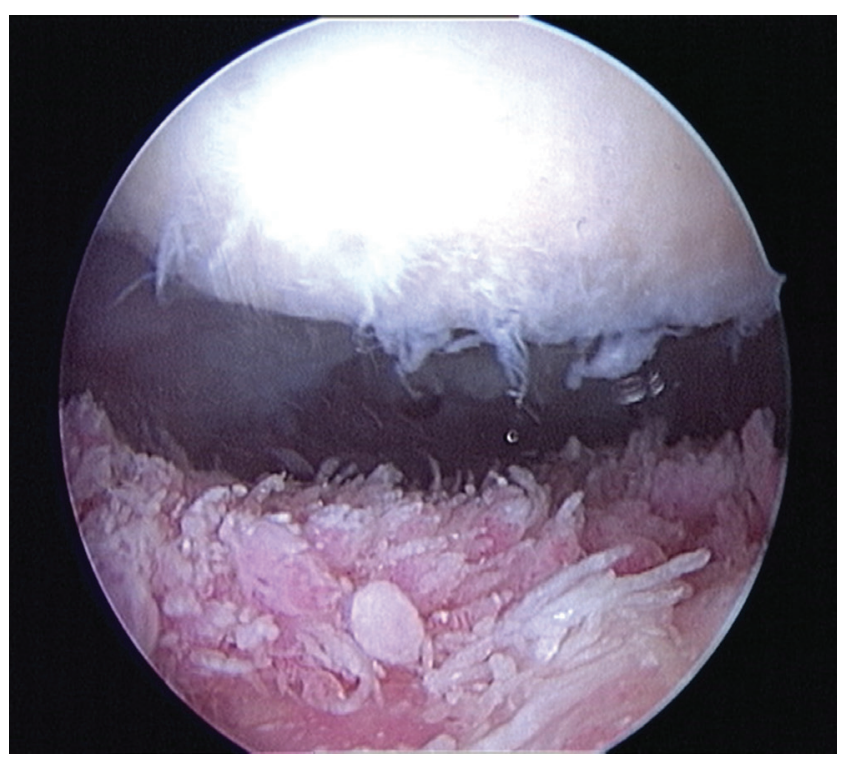

1. ábra $\mid$ A synovium szőlőfürtszerű burjánzást mutat, hyperaemiás, oedemás, vérzékeny 


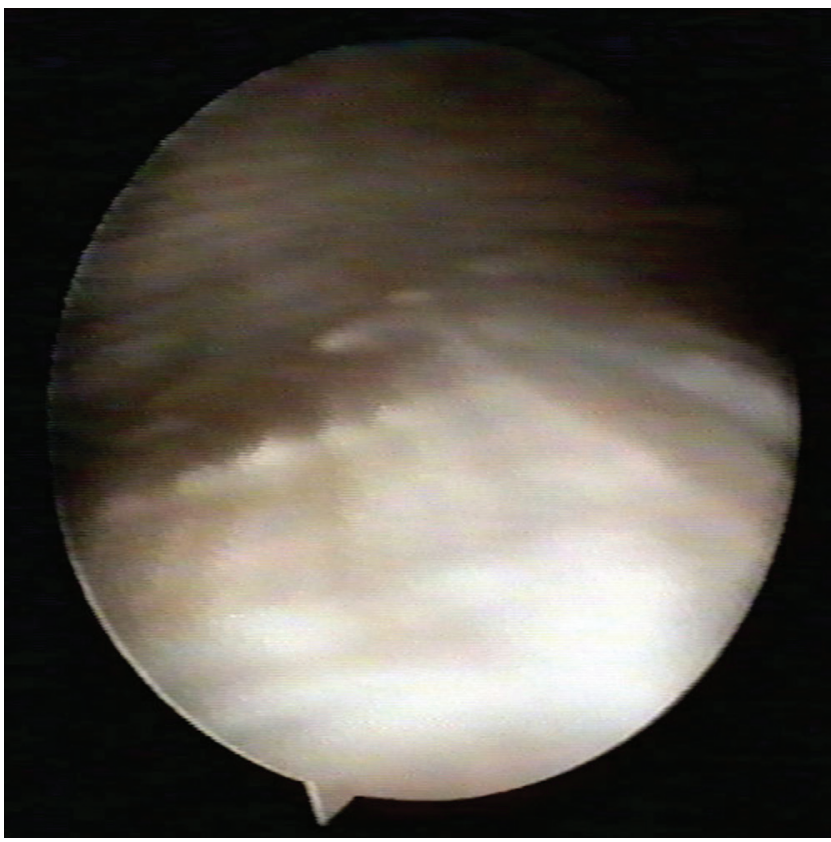

2. ábra $\mid$ A synovium szőlőfürtszerú burjánzása, a hyperaemia, oedema, vérzékenység megszűnt, sivatagszerủ kép alakult ki megszünt; a felszín elsimult és „sivatagszerü” az artroszkópos felvételen (2. ábra).

A szövettani metszeteken a kezelés elött a felszínen 3-4 synoviocytaréteg látható, alatta diffúz inflammatorikus infiltrátumokkal (3. ábra). A kezelés után a felszínt már csak 2 rétegü synoviocyta borítja: kevesebb a gyulladásos beszûrődés, és szövettanilag már látható a fibrosis (4. ábra).

Ultrahangvizsgálat 25 betegnél az RSO után 5 évvel is készült: mind a synovialis folyadék mennyiségének, mind a synovium rétegvastagságának szignifikáns csökkenését észleltük, tükrözve a klinikai javulást [25].

\section{Megbeszélés}

A synovitis megjelenése előre jelzi a betegség kialakulását, és a fájdalom hátterében áll. Ez a gyulladásos szövet lett a gyulladásgátló kezelések fó célpontja [26].

Megemlítik, hogy a szteroidos szimptomatikus fájdalomcsillapítás csak 3-4 hétig tart, és az ízületi funkciók nem javulnak [27]. Hasonló adatokat közölt a Royal College of Physicians [28]. A kortikoszteroidok adásának dózisa és gyakorisága nem egyértelmú [29-33]. Hatásukat rövidnek tartják, ahogy az ízületi funkciók javulását is, illetve az életminőség-javulást [34]. Ugyanakkor a szteroidkezeléseket nem lehet összehasonlítani az RSO-val, tekintettel arra, hogy a kezelés utáni hetekben a szteroidok hatása fokozatosan csökken, a radiációs kolloidok pedig lassabban (akár 6 hónap alatt) fejtik ki teljes hatásukat.

OA-ban eddig nem publikáltak prospektív, obszervációs vizsgálatot. Egyetlen vizsgálatban volt az átlagos utánkövetési idő 41 hónap [35], amelyben 68\%-ban ki-

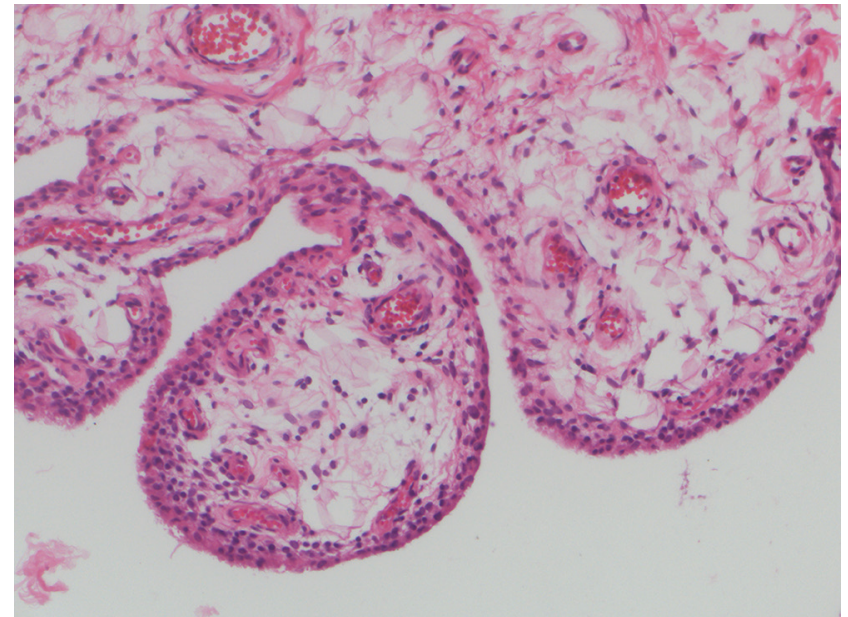

3. ábra

A felszínen 4 rétegú synoviocyta, a felszín alatt lymphocytás, plazmasejtes infiltráció

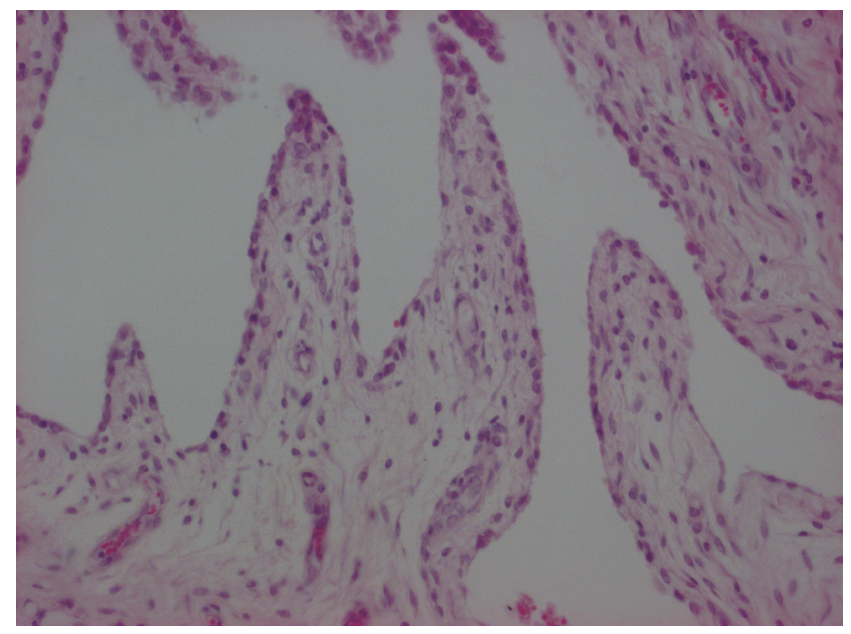

4. ábra

A felszínen 2 rétegú synoviocyta, a gyulladásos beszúrődés visszahúzódott, fibrosis jelei láthatók

váló eredményeket találtak. 1995-ban a saját csoportunk számolt be RA- és non-RA-betegek adatairól: 70\%-ban kiváló és jó eredményeket értünk el a 4. év végére, illetve az eredményesség 65\%-ra csökkent az 5 . év végére [36].

Kresnik és mtsai 2002-ben közöltek egy metaanalízist, amelyben 2190 ízület kezelését összesítették, bár az utánkövetés csak 1 év volt. Ebben az elemzésben csak 121 OA-beteg szerepelt. Az átlagos javulás 72,5 $\pm 17 \%$ volt, de OA esetében csak $56 \pm 11 \%$, világos trendet mutatva jobb eredmények elérésére azokban a betegekben, akikben a radiológiai eltérések csak minimálisak voltak. Hasonló volt a trend azokban a RA-betegekben, akik Steinbrocker I. stádiumúak voltak $(72,8 \pm 12,5 \%)$, azokhoz viszonyítva, akik a II. stádiumba tartoztak (64 \pm 17,3\%). Ha más funkciókat - mint a fájdalom csökkenése vagy az ízületi funkciók javulása - nézünk, akkor szintén különbség volt észlelhető a RA (>80\%) és az OA (60- 
80\%) javulása között [37]. Az összesítések szerint a mellékhatások elófordulása alacsony volt $[38,39]$.

Az OA és a RA radiosynovectomiával való kezelésének különbségéről más szerzők is publikáltak, mint például Zuderman és mtsai: 136 terápiarezisztens OA-beteg 424 ízületét kezelték RSO-val. Az ízületek nagyságától függetlenül szignifikáns különbség volt az eredményességben: a RA-ízületek 89\%-ban, az OA-ízületek 79\%-ban reagáltak jól. A nagy térdízületben a különbség még kifejezettebb volt ( $88 \%$ vs. $70 \%$ ) [40].

2014-ben egy ausztrál csoport retrospektív adatokat közölt [41]. A 129 OA-betegből 116 érte el a 3 éves nyomon követést. Ráadásul a térdízületeken kívül l csípőt, 1 bokát és 19 könyökízületet kezeltek 90-Yttriummal, amely az EANM-irányvonalak szerint csak a térdízületek kezelésére alkalmas a nagy penetrációs mélysége miatt, a csípő, a könyök és a boka kezelésére a kisebb energiájú és áthatolóképességú 186-réniumot vagy 166-holmiumot kell adni [23]. A betegeket először 3 hónap után, majd évente ellenőrizték, és az RSO 59\%ban $(68 / 116)$ volt sikeres.

A mi vizsgálatainkban [42] az ízületek gyulladásos és funkcionális eltéréseit objektíven és szubjektíven is mértük az összetett pontozási rendszerrel (1. és 2. táblázat). $\mathrm{Ez}$ az index sokféle szempontot vett figyelembe, mint például a klinikai paramétereket: az ízület körfogatát, hőmérsékletét, a járáskészséget, a nyugalmi és a terhelési fájdalmat (amelyet értékelni kellett a szubjektív skálán is). Hogy minél objektívebb legyen a megítélés, a kezelóorvos összehasonlította a paramétereket a beavatkozás előtti állapottal. Az adatokat összegyújtöttük a beadás után 1 évvel, majd 5 évvel, illetve utána minden évben. Alcsoportelemzések történtek a teljes betegszámra vs. K-L I-II. és III. stádiumú betegekre vonatkozóan (4. és 5. táblázat), a nemzetközi elemzésekhez hasonlóan [37-40].

A teljes betegpopuláció ( $\mathrm{n}=141$ ) eredményei hasonlóak voltak a nemzetközi eredményekhez, azaz „kiváló/ jó" eredményt mutattak az 1 éves kontrollvizsgálatnál $(63,8 \%)$, és $54,5 \%$-ot értek el a 10 éves ellenőrzéseken (3. táblázat). A K-L I-II. csoportban (4. táblázat) „kiváló/jó" eredmény volt az esetek 73,7\%-ában a 8 . évben. A K-L III. alcsoportban (5. táblázat) nem volt szignifikáns csökkenés egészen a 8 . évig $(45,9 \%$ vs. $41,2 \%)$. A 8 . év után elég magas volt a betegek kiesése a vizsgálatból, így az utolsó két évet nem lehetett figyelembe venni.

Jahangier és mtsai [43] 2006-ban bebizonyították, hogy a kezelések eredményessége függ a kezelés előtti synovialis makrofáginfiltrációtól mind a RA-, mind a non-RA-betegekben. Ahol kifejezett makrofáginfiltrációt észleltek, ott jobb klinikai eredményeket értek el az RSO alkalmazása révén.

Krenn és mtsai [44] 2006-ban közölték a „synovitis score" mérését, ezáltal elkülönítve bizonyos reumatológiai betegségeket (5. ábra), amelyek különbözőképpen veszik fel a radiokolloidokat a gyulladásnak megfelelően;

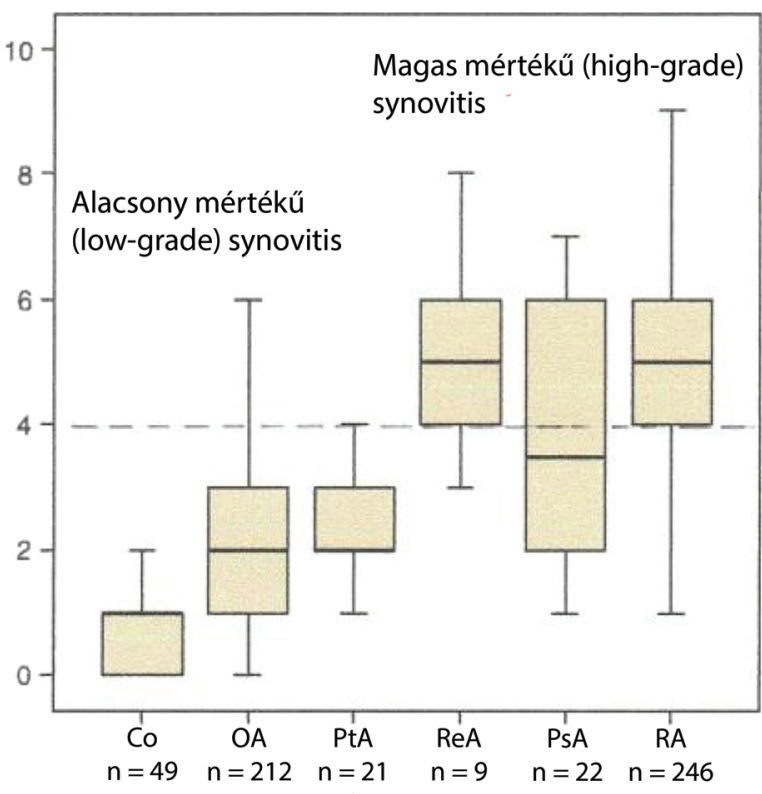

Klinikai diagnózisok

Co $=$ control group, kontrollcsoport

$\mathrm{OA}=$ osteoarthritis

PtA = posttraumás arthritis

$\operatorname{Re} A=$ reaktív arthritis

PsA $=$ arthritis psoriatica

$\mathrm{RA}=$ rheumatoid arthritis

Módosítva Krenn et al., Histopatology 2006; 49 (4) alapján \begin{tabular}{l|l} 
5. ábra & $\begin{array}{l}\text { Synovitis score a gyulladásos ízületi betegségek megkülönbözte- } \\
\text { tésére }\end{array}$
\end{tabular}

egyben bebizonyítva, hogy OA-betegek rendelkezhetnek magas score-értékekkel. A synovialis score-ban látható különbségek magyarázzák a különböző betegségek radiokolloid-felvételét és ezáltal a klinikai választ: a kontrollcsoporthoz $(\mathrm{Co})$ viszonyítva az OA és a posttraumás arthritis (PtA) nagyobb mértékben, míg a reaktív arthritis ( ReA), a RA, illetve az arthritis psoriatica (PsA) még nagyobb mértékben vette fel a kolloidot. A radiokolloid beadása utáni első 6 hónapban végbemennek a makroszkopikus és mikroszkopikus változások, ahogy azt az artroszkópos és biopsziás szövettani vizsgálatok mutatták, és ezek a következő években nem változnak [36].

A súlyos mellékhatások nagyon ritkák az RSO mellett, 900000 kezelt ízületre 1990-2011 között csak 30-at jelentettek [38, 45]. Feltételezhető, hogy ez a szám valamivel magasabb, de a súlyos mellékhatások száma így is 1\%o alatt marad. Hosszú távú eredményeket Kampen [46] és Szentesi $[47,48]$ közöltek. Metaanalízisek és szisztematikus áttekintő közlemények születtek több szerzőtől, mint Heuft-Dorenbosch [49], Van der Zant [50] és Kresnik [37]. Hasonló eredményeket közöltek 166-holmium alkalmazása esetén [51]. A krónikus gyulladásos reumatológiai kórképekben a fájdalomcsillapítás a mai napig kihívás marad [52]. Leghatásosabb az alapbetegség kezelése, de idősebb életkorban a gyógyszeres és sebészeti beavatkozásoknak már magas a rizikója [53]. 


\section{Következtetések}

A radiokolloidok alkalmazásának elsődleges célja a fájdalom és az ízületi folyadékgyülem csökkentése, valamint a funkcionalitás visszaállítása. Korai stádiumban levő OA esetében ezek a célkitűzések elérhetók. A helyileg alkalmazott béta-sugárzó kolloid csökkenti a synovium gyulladását, egyben késleltetve az ízület további romlását. A kezelés sikere függ attól, hogy a beteg ízületei milyen morfológiai állapotban vannak, azaz a legjobb eredmények olyan betegekben érhetők el, akik a K-L I-II. radiológiai stádiumba tartoznak. Különösen előnyösen lehet alkalmazni az RSO-t inoperábilis betegekben vagy más, súlyos rizikófaktorokkal és betegségekkel rendelkező betegekben, akiknél a protézismütét kontraindikált. Az RSO végzésével a protézismútéteket lehet késleltetni. A bemutatott vizsgálat megerősíti az RSO hosszú távú hatékonyságát a terápiarezisztens, perzisztens, fájdalmas térdízületi osteoarthrosisban. „Kitünő/jó” válasz volt elérhető a K-L I. vagy II. stádiumban levő betegekben, amikor már egyetlen radiokolloid-injekció is hatékony volt. Relatíve szerényebb eredmények érhetők el a K-L III. stádiumban levő betegeknél.

\section{Etikai jóváhagyás}

Ezt a prospektív tanulmányt 2008. szeptember 2-án jóváhagyta a Semmelweis Egyetem, amelyet 2019. március 27-én megerősítettek (dr. Rojkovich Bernadette, dr. Gyenei László). A humán résztvevőket bevonó tanulmányban elvégzett valamennyi eljárás összhangban volt az intézményi és nemzeti kutatási bizottság etikai normáival, valamint az 1964. évi helsinki nyilatkozattal és annak későbbi módosításaival.

Anyagi támogatás: A prospektív vizsgálat elkészítéséhez a szerzők semmiféle támogatást nem kaptak.

Szerzôi munkamegosztás: A kézirat elkészítéséhez a szerzők egyenlő mértékben járultak hozzá. A cikk végső változatát valamennyi szerző elolvasta és jóváhagyta.

Érdekeltségek: A szerzőknek nincsenek érdekeltségeik.

\section{Irodalom}

[1] Klippel JH, Dieppe PA. (eds). Rheumatology. 2nd edn. Mosby, St. Louis, MO, 1998.

[2] Conaghan PG, Kloppenburg M, Schett G, et al. Osteoarthritis research priorities: a report from a EULAR ad hoc expert committee. Ann Rheum Dis. 2014; 73: 1442-1445.

[3] Fransen M, Bridgett L, March L, et al. The epidemiology of osteoarthritis in Asia. Int J Rheum Dis. 2011; 14: 113-121.

[4] March LM, Bachmeier CJ. Economics of osteoarthritis: a global perspective. Baillieres Clin Rheumatol. 1997; 11: 817-834.

[5] Reginster JY, Khaltaev NG. Introduction and WHO perspective on the global burden of musculoskeletal conditions. Rheumatology 2002; 41(Suppl 1): 1-2.
[6] Malemud CJ. Biological basis of osteoarthritis: state of the evidence. Curr Opin Rheumatol. 2015; 27: 289-294.

[7] Fernandes JC, Martel-Pelletier J, Pelletier JP. The role of cytokines in osteoarthritis pathophysiology. Biorheology 2002; 39: 237-246.

[8] Hulejová H, Baresová V, Klézl Z, et al. Increased level of cytokines and matrix metalloproteinases in osteoarthritic subchondral bone. Cytokine 2017; 38: 151-156.

[9] Rubin BR. Management of osteoarthritic knee pain. J Am Osteopath Assoc. 2005; 105(9 Suppl 4): S23-S28.

[10] Peat G, McCarney R, Croft P. Knee pain and osteoarthritis in older adults: a review of community burden and current use of primary health care. Ann Rheum Dis. 2001; 60: 91-97.

[11] Walker EA, Davis D, Mosher TJ. Rapidly progressive osteoarthritis: biomechanical considerations. Magn Reson Imaging Clin N Am. 2011; 19: 283-294.

[12] Lequesne M, Amouroux J. Rapid destructive coxarthrosis. [La coxarthrose destructrice rapide.] Presse Med. 1970; 78: 14351439. [French]

[13] Nwosu LN, Mapp PI, Chapman V, et al. Relationship between structural pathology and pain behaviour in a model of osteoarthritis (OA). Osteoarthr Cartilage 2016; 24: 1910-1917.

[14] Miller RE, Malfait AM, Block JA, et al. Current status of nerve growth factor antibodies for the treatment of osteoarthritis pain. Clin Exp Rheumatol. 2017; 35(Suppl 107): 85-87.

[15] McMahon SB, Bennett DL, Priestley JV, et al. The biological effects of endogenous nerve growth factor on adult sensory neurons revealed by a trkA-IgG fusion molecule. Nat Med. 1995; 1 : 774-780.

[16] Neogi T, Guermazi A, Roemer F, et al. Association of joint inflammation with pain sensitization in knee osteoarthritis: a multicenter osteoarthritis study. Arthritis Rheumatol. 2016; 68: 654-661.

[17] Mathiessen A, Conaghan PG. Synovitis in osteoarthritis: current understanding with therapeutic implications. Arthritis Res Ther. 2017; 19: 18 .

[18] Gent YY, ter Wee MM, Voskuyl AE et al., Subclinical synovitis detected by macrophage PET, but not MRI, is related to shortterm flare of clinical disease activity in early RA patients: an exploratory study. Arthritis Res Ther. 2015; 17: 266.

[19] O’Neill TW, Parkes MJ, Maricar N, et al. Synovial tissue volume: a treatment target in knee osteoarthritis $(\mathrm{OA})$. Ann Rheum Dis. 2016; 75: 84-90.

[20] Fellinger K, Schmid J. Local therapy of rheumatic diseases [Die lokale Behandlung der rheumatischen Erkrankungen.] Wien Z Inn Med. 1952; 33: 351-363. [German]

[21] Aletaha D, Neogi T, Silman AJ, et al. 2010 Rheumatoid arthritis classifcation criteria: an American College of Rheumatology/ European League Against Rheumatism collaboration initiative. Arthritis Rheum. 2010; 62: 2569-2581.

[22] Kellgren JH, Lawrence JS. Radiological assessment of osteoarthritis. Ann Rheum Dis. 1957; 16: 494-502.

[23] Clunie G, Fischer M. EANM procedure guidelines for radiosynovectomy. Eur J Nucl Med. 2003; 30: BP12-BPl6.

[24] Szentesi M, Piroska E. Yttrium-90 radiosynoviorthesis in rheumatoid and traumatic chronic synovitis of the knee. Comparative evaluation. [Yttrium-90 radiosynoviorthesis rheumatoid és traumás térdízületi synovitisben. Összehasonlító tanulmány.] Magy Traumatol Orthop Kézseb Plaszt Seb. 1996; 39: 129-134. [Hungarian]

[25] Szentesi M, Berkes I, Tanka D, et al. Macroscopic and microscopic changes following Yttrium-90 radiosynoviorthesis in rheumatoid arthritis. [Makroszkópos és mikroszkópos elváltozások az Yttrium-90 radiosynoviorthesisel kezelt rheumatoid arthritises betegekben.] Hung Rev Sports Med. 1994; 35: 107116. [Hungarian] 
[26] Atukorala I, Kwoh CK, Guermazi A, et al. Synovitis in knee osteoarthritis: a precursor of disease? Ann Rheum Dis. 2016; 75: 390-395.

[27] Royal College of Physicians. Osteoarthritis - national clinical guideline for care and management in adults. Lavenham Press, Sudbury, 2008.

[28] Richmond J, Hunter D, Irrgang J, et al. Treatment of osteoarthritis of the knee (non-arthroplasty). J Am Acad Orthop Surg. 2009; 17: 591-600.

[29] Tracy CL, Edison JD. Intra-articular corticosteroid treatment of inflammatory joint diseases. In: Kampen WU, Fischer M. (eds.) Local treatment of inflammatory joint diseases. Benefits and risks. Springer, Heidelberg, 2015; pp. 49-52.

[30] Weber M. Rational intra-articular corticoid injection. [Rationale intraartikuläre Kortikosteroid-Injektion.] Schweiz Med Wochenschr. 1997; 127: 945-953. [German]

[31] Wernecke C, Braun HJ, Dragoo JL. The effect of intra-articular corticosteroids on articular cartilage - a systemic review. Orthop J Sports Med. 2015; 3: 2325967115581163.

[32] McAlindon TE, LaValley MP, Harvey WF, et al. Effect of intraarticular triamcinolone vs saline on knee cartilage volume and pain in patients with knee osteoarthritis. A randomized clinical trial. JAMA 2017; 317: 1967-1975.

[33] Raynauld JP, Buckland-Wright C, Ward R, et al. Safety and efficacy of long-term intra-articular steroid injections in osteoarthritis of the knee - a randomized, double blind, placebo-controlled trial. Arthritis Rheum. 2003; 48: 370-377.

[34] Jüni P, Hari R, Rutjes AW, et al. Intra-articular corticosteroid knee osteoarthritis. Cochrane Database Syst Rev 2015; (10): CD005328.

[35] Kampen WU, Hellweg L, Massoudi-Nickel S, et al. Clinical efficacy of radiation synovectomy in digital joint osteoarthritis. Eur J Nucl Med Mol Imaging 2005; 32: 575-580.

[36] Szentesi M, Piroska E, Réti P. The effectiveness of ${ }^{90}$ Yttrium radiosynoviorthesis following orthopedic interventions. [Ortopédsebészeti mútétek után végzett Yttrium-90 radiosynoviorthesis eredményessége.] M Traum Orth. 1995; 38: 129-134. [Hungarian]

[37] Kresnik E, Mikosch P, Gallowitsch HJ, et al. Clinical outcome of radiosynoviorthesis: a meta-analysis including 2190 treated joints. Nucl Med Commun. 2002; 23: 683-688.

[38] Kampen WU, Matis E, Czech N, et al. Serious complications after radiosynoviorthesis. Survey on frequency and treatment modalities. Nuklearmedizin 2006; 45: 262-268.

[39] Chatzopoulos D, Moralidis E, Markou P, et al. Yttrium-90 radiation synovectomy in knee osteoarthritis: a prospective assessment at 6 and 12 months. Nucl Med Commun. 2009; 30: 472-479.

[40] Zuderman L, Liepe K, Zöphel K, et al. Radiosynoviorthesis (RSO): influencing factors and therapy monitoring. Ann Nucl Med Imaging. 2008; 22: 735-741.

[41] Wong Y, Cherk MH, Powell A, et al. Efficacy of yttrium-90 synovectomy across a spectrum of arthropathies in an era of im- proved disease modifying drugs and treatment protocols. Int J Rheum Dis. 2014; 17: 78-83.

[42] Szentesi M, Papp I, Farbaky Zs, et al. Treatment of chronic knee synovitis with radiosynoviorthesis after failure of surgical interventions. EC Orthopaedics. 2020; 11: 1-14.

[43] Jahangier ZN, Jacobs JW, Kraan MC, et al. Pretreatment macrophage infiltration of the synovium predicts the clinical effect of both radiation synovectomy and intra-articular glucocorticoids. Ann Rheum Dis. 2006; 65: 1286-1292.

[44] Krenn V, Morawietz L, Burmester GR, et al. Synovitis score: discrimination between chronic low-grade and high-grade synovitis. Histopathology. 2006; 49: 358-364.

[45] Fischer M, Brinker A, Sickmüller B. Safety of medicines: detection and reporting adverse reactions. In: Kampen WU, Fischer M. (eds.) Local treatment of inflammatory joint diseases. Benefits and risks. Springer, Heidelberg, 2015; pp. 1-27.

[46] Kampen, WU, Brenner W, Kroeger S, et al. Long-term results of radiation synovectomy: a clinical follow-up study. Nucl Med Commun. 2001; 22: 239-246.

[47] Szentesi M, Nagy Z, Géher P, et al. A prospective observational study on the long-term results of ${ }^{90} \mathrm{Yttrium}$ citrate radiosynoviorthesis of synovitis in osteoarthritis of the knee joint. Eur J Nucl Med Mol Imaging. 2019; 46: 1633-1641.

[48] Szentesi M, Nagy Z, Mangel ZsK, et al. Biological therapy and radiosynoviorthesis in patients with rheumatoid arthritis and psoriatic arthritis. Ann Rheum Dis. 2019; 78(Suppl 2): 1686.

[49] Heuft-Dorenbosch LL, de Vet HC, van der Linden S. Yttrium radiosynoviorthesis in the treatment of knee arthritis in rheumatoid arthritis: a systematic review. Ann Rheum Dis. 2000; 59: 583-586.

[50] Van der Zant FM, Boer RO, Moolenburgh JD, et al. Radiation synovectomy with ${ }^{90}$ Yttrium, ${ }^{186}$ Rhenium and ${ }^{169}$ Erbium: a systematic literature review with meta-analyses. Clin Exp Rheumatol. 2009; 27: 130-139.

[51] Szentesi M, Nagy Z, Geher P. 166-Holmium-phytate radiosynoviorthesis in rheumatoid arthritis. Five years clinical result, phase III prospective study. Nucl Med. Review 2009; 12: P17.

[52] Szamosi Sz. Recommendation for the substantial choice between various nonsteroidal antiinflammatory drugs based on their safety profile. [A nemszteroid gyulladáscsökkentő gyógyszerek kiválasztásának szempontjai a biztonságosság tükrében.] Orv Hetil. 2018; 159: 1783-1788. [Hungarian]

[53] [53] Sütő G. Non-steroidal anti-inflammatory drugs for relieving pain in musculoskeletal disorders. [Nemszteroid gyulladáscsökkentő szerek a mozgásszervi fájdalom csillapításában.] Orv Hetil. 2019; 160: 885-860. [Hungarian]

(Szentesi Margit dr., Budapest, Árpád fejedelem útja 7., 1027 e-mail: szentesi.margit@gmail.com)

A cikk a Creative Commons Attribution 4.0 International License (https://creativecommons.org/licenses/by-nc/4.0/) feltételei szerint publikált Open Access közlemény, melynek szellemében a cikk bármilyen médiumban szabadon felhasználható, megosztható és újraközölhető, feltéve, hogy az eredeti szerző és a közlés helye illetve a CC License linkje és az esetlegesen végrehaitott módositások feltüntetésre kerülnek. 